Article

\title{
A Knot Not to Be Cut? The Legacy of Brexit over the CJEU
}

\author{
Marta Simoncini ${ }^{1, *}$ and Giuseppe Martinico ${ }^{2}$ \\ ${ }^{1}$ Department of Political Sciences, Luiss University, 00197 Rome, Italy; E-Mail: msimoncini@luiss.it \\ 2 DIRPOLIS, Sant'Anna School of Advanced Studies, 56127 Pisa, Italy; E-Mail: giuseppe.martinico@santannapisa.it \\ * Corresponding author
}

Submitted: 15 September 2020 | Accepted: 26 October 2020 | Published: 27 January 2021

\begin{abstract}
What was the role of the Court of Justice of the European Union (CJEU) in the Brexit saga? And what will the impact of Brexit be over the future structure and activity of the CJEU? This article deals with this twofold question and explores three different issues. Firstly, we will offer a reflection on the questions and the risks raised by the Wightman case, where the CJEU ruled on the unilateral revocation of the UK notification of its intention to withdraw from the European Union under Art. 50 Treaty of the EU. Secondly, we will analyse the impact of Brexit on the composition of the CJEU and, particularly, the risks for the independence of the Court raised by the advanced termination of the mandate of the British Advocate General. Thirdly, we will provide some insights on the scope of the jurisdiction of the CJEU in the post-Brexit Union, emphasising how the Withdrawal Agreement maintained its jurisdiction during and even beyond the transition period. This article reflects the events that took place up to 6 October 2020 .
\end{abstract}

\section{Keywords}

Advocate General; Brexit; Court of Justice of the European Union; EU law; interpretation; post-Brexit EU

Issue

This article is part of the issue "What Brexit Means for Europe: EU Institutions and Actors after the British Referendum" edited by Edoardo Bressanelli (Sant'Anna School of Advanced Studies, Italy) and Nicola Chelotti (Loughborough University London, UK).

(C) 2021 by the authors; licensee Cogitatio (Lisbon, Portugal). This article is licensed under a Creative Commons Attribution 4.0 International License (CC BY).

\section{Introduction}

In Bulmer (HP) Ltd v. J Bollinger SA (1974) Lord Denning, one of the most influent lawyers in the history of the United Kingdom (UK), described the impact of Community law over the British legal system by using the image of the "incoming tide" which "flows into the estuaries and up the rivers. It cannot be held back." The irony in this is that Brexit can be defined as an effort to push the tide of EU law back to recover the original meaning of British sovereignty, understood as parliamentary supremacy (Dicey, 1885) in a context characterised by a partly written constitution. This is a legal system characterised by a "process of gradually converting an uncodified constitution into a codified one" (Bogdanor, Khaitan, \& Vogenauer, 2010), so that fundamental aspects of the British constitution are not governed by statutes or written norms (Bogdanor, 2019). From the EU perspec- tive, the Brexit saga was a shocking turning point, the moment of rupture with its traditional "awkward partner" (George, 1990). In this saga, the Court of Justice of the European Union (CJEU) played a relevant role and contributed to disclosing the tensions between the respect for national sovereignty and the independence of supranational institutions.

The purpose of this article is twofold: to investigate the role of the CJEU during the Brexit process and the possible impact of the British withdrawal of the European Union (EU) membership on the composition and jurisdiction of the Court. The centrality of the CJEU as acknowledged by the wording of the Withdrawal Agreement (hereafter WA; Council of the European Union, 2019; see also Council of the European Union, 2020) derived from the existence of a legal 'knot,' that is, the web of norms created by years of membership of the UK within the EU. As evidence of this, consid- 
er that EU law has over the years contributed to creating new rights that have partly been retained by the domestic norms governing the repeal of EU law in the UK (see UK Parliament, 2018). Another example of the complex context triggered by the Europeanisation of the British system is the first Miller case, firstly heard before the High Court ( $R$ [Miller] $v$. Secretary of State for Exiting the European Union, 2016) and then before the UK Supreme Court ( $R$ [Miller] v. Secretary of State for Exiting the European Union, 2017), which emphasised the importance of the EU integration for the genesis of a new category of rights. In addition, a series of recent cases concerning the validity of the Council Decision (EU) 2020/135 (Council of the European Union, 2020) as regards the breach of EU citizenship rights also shows how difficult it is to cut legal ties without breaking fundamental rights that became part of the British constitution (see $J U$ and Others v. Council, pending; Price v. Council, pending; Shindler and Others v. Council, pending). All this means that the EU membership has created a constitutional legacy in the UK that will not be cancelled: it is a legal knot that cannot easily be cut.

Alongside the several economic and political issues that needed to be settled, the legal ties connecting the Member States in the EU legal order and governing such economic and political relationships indeed emerged as a critical knot in the Brexit process. By triggering the withdrawal process, the UK has not only mobilised political actors and their negotiations, but it has also shaken the existing legal interdependences, which remained relevant for all the time that the UK continued to be a Member State and will still affect to some extent the post-Brexit Union. The CJEU as the guardian of the Treaties has thus become a key player to unleash conflicts in the withdrawal process.

This article focuses on the role of the CJEU in Brexit, with the aim of disclosing the main legacies of Brexit from the perspective of this key institution. The analysis is thus divided into three parts, each highlighting the main issues of the two research questions recalled above. The first part (Sections 2 and 3 ) examines how the CJEU contributed to interpreting Art. 50 of the Treaty of the EU (TEU), which guided the Brexit process. The analysis is thus centred on the Wightman case, which set a milestone in the governance of the withdrawal process. The subsequent parts focus on how Brexit will likely influence the role of the CJEU in the post-Brexit Union. They are thus devoted to the analysis of the independence of the Court (Section 4) and the scope of its jurisdiction (Section 5) in the post-Brexit Union. The final remarks highlight the importance of Brexit for the future case law of the CJEU.

\section{Brexit and National Sovereignty in the EU Legal Order}

During the Brexit process, the CJEU was called to interpret Art. 50 TEU under preliminary ruling proceedings in the case Andy Wightman and Others v. Secretary of State for Exiting the European Union (2018). The preliminary ruling has worked as a powerful bridge connecting national judges and the CJEU. According to Art. 267 TFEU governing the procedure, national judges may or shall raise preliminary questions to the CJEU concerning either the validity or the interpretation of EU law if these questions are necessary to solve a national case. In the Wightman case, the Scottish Inner Court of Session asked the CJEU to clarify whether the British decision of withdrawal could be revoked unilaterally. The national court raised the question because Art. 50 TEU did not expressly regulate the right to revocation of the notification to withdraw. In its capacity of exclusive interpreter of the Treaties, the CJEU had to rule on whether such revocation was admissible, and if so, whether it could be unilateral or should be subject to specific conditions.

When deciding on a number of crucial aspects governing the departure of a Member State from the EU, the CJEU contributed not only to clarifying the viable options concerning Brexit, but also offering several insights on the nature of the EU legal order itself (Martinico \& Simoncini, 2020). It particularly emphasised the precedence of national sovereignty in the decision to withdraw the membership and reverse such a decision, over any other considerations of supranational autonomy and the legitimate expectations of the remaining Member States.

Both Advocate General (AG) Campos SánchezBordona and the Grand Chamber of the Court recognised that Art. 50 TEU neither prohibits expressly nor authorises explicitly any form of revocation of the withdrawal notification, but they identified behind the legal minimalism of Art. 50 TEU the existence of a sovereign right of the Member State to reverse the withdrawal process. When filling the lacuna in the black letter of the law, their respective interpretations however differed in the conceptualisation of such right and the conditions for its exercise.

AG Campos Sánchez-Bordona relied on international law and held Art. 50 TEU as "lex specialis, in respect of the general rules of international law on withdrawal from treaties, but not a self-contained provision which exhaustively governs each and every detail of the withdrawal process" (Campos Sánchez-Bordona, 2018, para. 85). The CJEU, instead, refused to treat the withdrawal and its reversal as an international law issue related to the participation of States in a Treaty and reaffirmed the difference between the EU legal order and "ordinary international treaties" (Andy Wightman and Others v. Secretary of State for Exiting the European Union, 2018, para. 44), considering its findings "only corroborated by the provisions of the Vienna Convention on the Law of the Treaties" (Campos Sánchez-Bordona, 2018, para. 70). The Court started its reasoning from the idea that the EU is an autonomous legal order with its own institutions and independent sources of law. It thus justified its interpretation on the grounds of the "structured network of principles, rules and mutually interdependent legal rela- 
tions binding the EU and its Member States reciprocally as well as binding its Member States to each other" (Campos Sánchez-Bordona, 2018, para. 45).

The Court stressed the autonomy of EU law and marked the distinctiveness of EU law and dualism in the application of international law. The EU legal order shall be protected against the external interference of international law, including in the foundational moment of withdrawal. Wightman reiterated the consistency of the case law since the Van Gend and Loos case (NV Algemene Transport- en Expeditie Onderneming van Gend \& Loos v. Netherlands Inland Revenue Administration, 1963), which "expressly cut the umbilical cord with classic international law" (Schütze, 2015, p. 79). The autonomy of EU law thus brings about the assessment of the relevant question in light of the Treaties. The Court emphasised this approach both in the Kadi case when assessing the validity of restrictions imposed on suspected terrorists (Yassin Abdullah Kadi and Al Barakaat International Foundation v. Council of the European Union and Commission of the European Communities, 2008; see also Avbelj, Fontanelli, \& Martinico, 2014; Simoncini, 2009) and in the Opinion 2/13 on the EU accession to the European Convention of Human Rights (Court of Justice of the European Union, 2014; see also Eeckhout, 2015)-both referred to in Wightman.

The CJEU reconnected the right of withdrawal to the right of the State "to retain its status as a Member State of the European Union, a status which is not suspended or altered by that notification" (Andy Wightman and Others v. Secretary of State for Exiting the European Union, 2018, para. 59). The Court focused on the Member States' commitment to the common values of integration and the goals of the EU project and emphasised that no Member State can be forced to leave against its own will (Andy Wightman and Others $v$. Secretary of State for Exiting the European Union, 2018, para. 66). As Frantziou and Eeckhout (2017, pp. 699-700, 702-703) underlined, such interdependence means that a complex system of rights is at stake in the withdrawal process and this requires a specific constitutional reading of Art. 50 TEU.

This characterisation of the sovereign right of the Member State to commit to and withdraw from the EU legal system persuaded the Court not to impose any condition on the exercise of this right. To avoid the risk of undue interferences with the right, the Court only required the revocation to be "unequivocal and unconditional, that is to say that purpose of that revocation is to confirm the EU membership of the Member State concerned under the terms that are unchanged as regards its status as a Member State, and that revocation brings the withdrawal procedure to an end" (Andy Wightman and Others v. Secretary of State for Exiting the European Union, 2018, para. 74).

The CJEU thus ruled against the Council and the Commission, which asked for the revocation to be subject to mutual consent through the unanimous approval of the European Council. The Court also deviated from the Opinion of the AG, who considered that the unilateral exercise of the right should be reasonably tempered to prevent procedural abuses. In the AG's interpretation, revocation should be exercised by ensuring mutual trust between the departing State and the EU and required reasonable justifications to ensure that collateral legal tactics do not drain negotiations and do not turn a right into a privilege.

The absence of procedural requirements, however, weakens the capability of the CJEU to control the authenticity of the reversal decision. When rejecting any conditions of mutuality, in fact, the Court implicitly required all the other Member States to trust the declaration of the State to reverse its withdrawal intentions unequivocally and unconditionally. The CJEU relied on the good faith of the decision of the departing State to genuinely reverse the withdrawal, and thus bound the remaining Member States to that decision. This means that the principle of mutual trust still applies in the relations between both un-departing Member States and the other Member States, because they are all committed to the same values. As the CJEU suggested-among others-in Opinion 2/13, mutual trust is a pillar of EU law, which operates as a presumption in the relations among Member States and as cases in asylum law show, can only be challenged under very specific circumstances (see Canor, 2013).

\section{Systemic Risks of the Wightman Ruling}

In Wightman, for the first time, the CJEU offered an interpretation of Art. 50 TEU, by reading this provision in combination with other norms of the Treaties and in light of some historical decisions. On the one hand, the Court recalled cases like Les Verts, Kadi and Opinion 2/13 to confirm the sui generis (and constitutional) nature of the EU (Andy Wightman and Others v. Secretary of State for Exiting the European Union, 2018, para. 44). On the other hand, the CJEU read Art. 50 TEU from the perspective of the values that characterise the supranational integration process (Sarmiento, 2018).

As regards the context of Article $50 \mathrm{TEU}$, reference must be made to the 13th recital in the preamble to the TEU, the first recital in the preamble to the TFEU and Article 1 TEU, which indicate that those treaties have as their purpose the creation of an ever closer union among the peoples of Europe, and to the second recital in the preamble to the TFEU, from which it follows that the EU aims to eliminate the barriers which divide Europe (European Union, 2016a, 2016b). It is also appropriate to underline the importance of:

The values of liberty and democracy, referred to in the second and fourth recitals of the preamble to the TEU, which are among the common values referred to in Article 2 of that Treaty and in the preamble to the Charter of Fundamental Rights of the EU, and 
which thus form part of the very foundations of the EU legal order (see to that effect, Yassin Abdullah Kadi and Al Barakaat International Foundation v. Council of the European Union and Commission of the European Communities, 2008, paras. 303-304). (Andy Wightman and Others v. Secretary of State for Exiting the European Union, 2018, para 62)

However, the reading proposed by the CJEU presents some risks. The language of the sovereign rights can expose the EU and the remaining States to abuses in the unilateral revocation of Art. 50 TEU. For instance, States could use the threat of exit to renegotiate better (from their point of view) conditions. To avoid this scenario, we think that "a sustainable reading of Art. 50 TEU" (Martinico \& Simoncini, 2020) is necessary to escape any instrumental (ab)uses of this norm. The frequent mention made by the CJEU of the concept of sovereignty is a ground of criticism in this respect, as it risks exposing Art. 50 TEU to perilous unilateral readings. The word "sovereign" was repeated six times in the English version of the Wightman, becoming its keyword. Such an emphasis on this concept remains unbalanced in so far as the CJEU did not refer to the principle of sincere cooperation. It seems to us that the Luxembourg Court excessively focused on an approach aimed at guaranteeing the sovereign choice at the costs of the plurilateral design of Art. 50 TEU. This creates a systemic risk, which may trigger serious instability in the withdrawal process. This risk is only mitigated by the fact that Art. 50 TEU cannot be read as if it were detached from the broader constellation of values preserved by the EU Treaties.

\section{The Independence of the CJEU in the Post-Brexit Union}

In accordance with Art. 50 (3) TEU, the Treaties cease to apply to the withdrawing Member State from the date of entry into force of the WA (European Union, 2016a). As stated in the Declaration of 29 January 2020 by the conference of the representatives of the Governments of the Member States (Conference of the Representatives of the Governments of the Member States, 2020, 29 January), the ongoing mandates of members of EU institutions, bodies, offices and agencies nominated, appointed or elected in relation to the UK's membership of the Union end on the date of withdrawal.

This affected the same composition of the CJEU. The British judges and the British AG, Eleonor Sharpston, were called to leave their mandates. If the departure of British judges stems from the black letter of Art. 19 (2) TEU, for the AG there is no specific legal basis that imposes such a choice. As under Art. 19 (2) TEU, in fact, both the General Court and the CJEU are composed of judges from each Member State, British judges had to terminate their mandate in advance.

It was the Declaration of 29 January 2020 that applied the same destiny to the AG permanently nomi- nated by the UK, but not legally constrained by nationality clauses. On the one hand, under Declaration 38 annexed to the Lisbon Treaty, the system of appointment of the AG provided that bigger Member States-that is, Germany, France, Italy, Spain, the UK and Polandshould permanently appoint six AGs, while the otherscurrently five-will rotate among the smaller States (European Union, 2016c). On the other hand, art. 8 of Protocol No 3 on the Statute of the CJEU extends to the Advocates-General the guarantees on the judges' immovability (European Union, 2016d). According to art. 5 replacement, death, resignation are the only reasons for dismissal normal, while under art. 6 deprivation of office may occur "only if, in the unanimous opinion of the Judges and Advocates General of the Court of Justice, he no longer fulfils the requisite conditions or meets the obligations arising from his office" (European Union, 2016d). No nationality requirement for the exercise of the AG's functions is envisaged.

There is no apparent legal basis for dismantling the guarantees that frame the functions of the British AG. Unlike for judges, no Treaty provision subordinates the functions of the Advocates General as members of the Court of Justice to nationality clauses; in addition, the Statute of the Court, which has the same force of the Treaties as primary law, does not provide any exclusion clause linked to national representation. This persuaded British AG Sharpston to act for the annulment of the decisions concerning her removal in two actions that were kept confidential. She asked for the annulment of the Declaration of 29 January 2020, insofar as it integrated her post in the rotation system among the Member States. She also challenged the letter of 31 January 2020 that the President of the CJEU, Koen Lenaerts, addressed to the President of the Council of the EU and of the Conference of the Representatives of the Governments of the Member States, Andrej Plenković, which confirmed the vacancy, while allowing her to keep the position until her own replacement.

More recently, Sharpston also acted for the annulment of Decision 2020/1251/EU (Representatives of the governments of the Member States, 2020) which appointed a new AG and she also asked for interim relief. Two orders of the Vice-President of the CJEU (Council of the European Union v. Eleanor Sharpston, 2020) set aside the previous order of the Judge of the General Court (see Eleanor Sharpston v. Council of the European Union and Representatives of the Governments of the Member States, 2020), granting as an interim measure the suspension of the Decision of the Representatives of the Governments of the Member State regarding the appointment of a new AG. In the first order, the Vice-President of the CJEU particularly found that the General Court had erred in law when granting interim measures, because the Decision 2020/1251/EU was an act of the Member States acting in the Conference of the Representatives of the Governments "collectively exercising the competences of the Member States" and not 
of the Council, so that their act could not be subject to judicial review by the EU courts (Representatives of the governments of the Member States, 2020, para. 26). When adjudicating the substance of the case, the General Court thus relied on this interpretation of the Vice-President of the CJEU and consequently dismissed the action for annulment on the grounds that there was no act adopted by an EU institution at stake that could be subject to the judicial review of the Court (see Eleanor Sharpston v. Council of the European Union and Representatives of the Governments of the Member States, 2020).

This intense litigation clearly shows the existing concerns about the risk for the lack of independence of the EU judicial branch and transparency since the AG Sharpston was dismissed and replaced after a series of decisions, which allegedly breached the relevant norms governing the procedure (Kochenov \& Butler, 2020a, 2020b, 2020c). The case discloses the tension between the political opportunity of keeping an AG appointed by the UK and the legal guarantees concerning the independence of such a role. The case is peculiar because the need to cut the political ties with the exiting Member State directly clashes with the principle of independence of courts that frames the rule of law in the EU and its Member States. The tensions between the principle of national sovereignty and the independence of EU institutions were brought within the organisation of the Court, showing the legal difficulties to cut the existing interdependences between national sovereignty and supranational autonomy. In other words, the case shows the latent conflict between the principle of intergovernmentalism, which relates to the principle of national sovereignty in the composition of EU institutions and the principle of independence of the judiciary, which lies at the roots of the rule of law and preserves the supranational function of the Court and its Advocates General.

For courts, independence has a specific legal meaning. Although the CJEU has strongly contributed to the implementation of the European project, its contribution was grounded on the judicial neutrality to the interests of the parties in the trial. Even more so, this applies to an organ like the AG, which performs serving functions aimed at the uniform interpretation and application of EU law by a Court composed of national judges. The independence of other institutions and, particularly, of the Commission, instead, is a means to pursue political goals. It is not neutrality to the interests at stake, but the discretionary capability to choose among the interests at stake and define how to best pursue supranational interests in a wider accountability framework.

Legal scholarship has effectively pointed out that the Declaration of 29 January 2020 has a clear political value, but it cannot reverse legal provisions of the Statute of the Court regulating AGs' appointment and removal, which have the force of primary law of the Treaties (Halberstam, 2020; Kochenov, 2020; Pech, 2020). Unlike protocols, declarations attached to the Treaties are non-binding statements. Declaration 38 thus cannot affect Art. 19 (2) TEU, according to which AGs "shall be appointed by common accord of the governments of the Member States for six years" and can be reappointed (European Union, 2016a). In addition, Halberstam (2020) considers that the recitals to the Brexit WA emphasising the end of the mandates of all members of institutions have no binding force and that the inclusion of AGs among the cohort of sacked officials does not necessarily flow from Art. 101 WA, which refers to continuing privileges and immunities of the members of institutions. He also questions whether the continuity of AG Sharpston's office until the appointment of the new AG might be an implicit admission of the legitimacy of her service. As Pech effectively held, "there cannot be an application à la carte of the CJEU Statute: Either AG Sharpston is covered by it or she isn't. She cannot be the Court's Schrödinger's AG," trapped in the sort of paradoxical situation proposed by the Nobel Prize physicist in his thought experiment of the cat both alive and dead at the same time (Pech, 2020).

To protect the independence of the Court and the rule of law, AG Sharpston should leave her position only at the expiration of her six-year mandate. Otherwise, there would be a breach of primary EU law "triggered by a political declaration combined with one of her nationalities," the British one (Kochenov, 2020). In Kochenov's words, the breach would create the conditions for "humiliating our own Court through undermining both its independence and its attempts to take the Rule of Law seriously in the current difficult circumstances" (Kochenov, 2020). Only the Court-according to its own Statute-should "exclusively decide on the legal effects of Brexit (if any) on the mandate of AG Sharpston. It is not for political actors to decide this matter, in particular via an entity which is not even mentioned once in either the TEU or the TFEU" (Pech, 2020).

The rule of law should thus confer precedence on the independent status of the Court, preserving its usual functioning despite the occurrence of an exceptional situation as Brexit is. Political changes shall not compromise the correct functioning of independent institutions, showing that the legal knot would not be cut where the law of the Treaties prevails over political will. The first findings on the AG Sharpston's case show that so far, the CJEU and the General Court have not entered the merit of this issue. Yet, it remains to be seen if and how the CJEU will reconcile its own independence with the dismissal of the AG in its next expected rulings.

\section{The Jurisdiction of the CJEU in the Post-Brexit Union}

On 1 October 2020 the Commission decided to trigger the procedure to bring the UK before the CJEU for violation of the WA. In particular, according to the Commission some parts of the British Internal Market Bill breaches the obligation of good faith enshrined in Art. 5 of the WA and it also conflicts with the Protocol 
on Ireland and Northern Ireland. It has been argued that the:

Internal Market Bill thus sets the scene for a perfect constitutional storm: a confrontation with the EU, a stand-off with the courts, a fundamental attack on the rule of law, and a diminution of the UK's commitment to the rules-based international order. (Elliott, 2020)

In particular, clauses 44,45 and 47 are the main sources of such a conflict. In a nutshell, they provide ministers with the "power to disapply or modify export declarations and other exit procedures," including "any exit procedure that is applicable by virtue of the Northern Ireland Protocol" (HM Government, 2020, clause 44). They also give ministers the power to disapply or modify the "effect of Article 10 of the Northern Ireland Protocol (State aid)" (HM Government, 2020, clause 45). Finally, clause 47 states that "regulations under section 44(1) or 45(1) are not to be regarded as unlawful on the grounds of any incompatibility or inconsistency with relevant international or domestic law" (HM Government, 2020). Clause 47, in particular, openly clashes with the principle of direct effect and with other norms of international law, as recognised by Northern Ireland Secretary Brandon Lewis, who spoke of a violation of international law "in a specific and limited way" at the House of Commons on 8 September 2020. On this basis the Commission activated the procedure. This episode is very telling of the central role that the CJEU can still play, especially in the transition period. This is confirmed by many provisions, among others, by Art. 131 of the WA, a clause functioning "as the juridical means to ensure the transition period maintains a 'simulacrum' of the supranational constitutional order in relation to the UK immediately following withdrawal" (Garner, 2020). This provision reads that:

During the transition period, the institutions, bodies, offices and agencies of the Union shall have the powers conferred upon them by Union law in relation to the UK and to natural and legal persons residing or established in the UK. In particular, the Court of Justice of the European Union shall have jurisdiction as provided for in the Treaties.

The first paragraph shall also apply during the transition period as regards the interpretation and application of this Agreement. (Council of the European Union, 2019, C 384 I/63)

Not by coincidence, this provision, among others, has created concerns and criticism among Brexiteers, as it seems to confirm "the 'after-life' of Article 258 TFEU before the end of the transitions period" (Garner, 2020). Art. 258 TFEU is about the so-called infringement procedure, i.e., the mechanism according to which the Commission may bring a State which does not comply with EU before the Luxembourg Court. This procedure is characterised by a pre-judicial phase in which the Commission asks (by means of a formal notice) the State to present its views regarding an alleged breach of EU law. In light of the information brought by the State the Commission may decide to send a formal request to comply with EU law and, eventually, to bring the case to the CJEU. Stepping back to the breach of the WA, in accordance with the terms of the agreement, the CJEU is to continue to have jurisdiction in any proceedings brought by or against the UK before the end of the transition period, which is set as 31 December 2020. It is also to continue to have jurisdiction to give preliminary rulings on requests from British courts and tribunals made before the end of the transition period. The WA also makes a distinction between pending cases (Art. 86) and new cases before the CJEU (Art. 87). Art. 87 WA is particularly intriguing as it reads:

1. If the European Commission considers that the UK has failed to fulfil an obligation under the Treaties or under Part Four of this Agreement before the end of the transition period, the European Commission may, within 4 years after the end of the transition period, bring the matter before the Court of Justice of the European Union in accordance with the requirements laid down in Article 258 TFEU or the second subparagraph of Article 108(2) TFEU, as the case may be. The Court of Justice of the European Union shall have jurisdiction over such cases.

2. If the UK does not comply with a decision referred to in Article 95(1) of this Agreement, or fails to give legal effect in the UK's legal order to a decision, as referred to in that provision, that was addressed to a natural or legal person residing or established in the UK, the European Commission may, within 4 years from the date of the decision concerned, bring the matter to the Court of Justice of the European Union in accordance with the requirements laid down in Article 258 TFEU or the second subparagraph of Article 108(2) TFEU, as the case may be. The Court of Justice of the European Union shall have jurisdiction over such cases.

3. In deciding to bring matters under this Article, the European Commission shall apply the same principles in respect of the UK as in respect of any Member State. (Council of the European Union, 2019, C 384 l/45)

This was one of the most contested provisions by the UK, since it extends the jurisdiction of the Court even after the end of the transition period. For the sake of clarity, Art. 89 WA confirms the binding nature of these kinds of judgements "in their entirety on and in the UK" (Council of the European Union, 2019, C 384 I/45). Another contested provision of the WA is Art. 158, according to which the CJEU has jurisdiction to give preliminary rulings on requests concerning cases "commenced at first instance 
within 8 years from the end of the transition period before a court or tribunal in the UK," where "a question is raised concerning the interpretation of Part Two of this Agreement, and where that court or tribunal considers that a decision on that question is necessary to enable it to give judgment in that case" (Council of the European Union, 2019, C 384 I/45-46).

A similar scheme is applied to cases concerning Art. 18 (Issuance of residence documents) and 19 (Issuance of residence documents during the transition period) of the Agreement. Finally, another confirmation of the persistence of the relevance of the case law of the Luxembourg Court can be found in Art. 174, which reads:

Where a dispute submitted to arbitration in accordance with this Title raises a question of interpretation of a concept of Union law, a question of interpretation of a provision of Union law referred to in this Agreement or a question of whether the United Kingdom has complied with its obligations under Article 89(2), the arbitration panel shall not decide on any such question. In such case, it shall request the Court of Justice of the European Union to give a ruling on the question. The Court of Justice of the European Union shall have jurisdiction to give such a ruling which shall be binding on the arbitration panel. The arbitration panel shall make the request referred to in the first subparagraph after having heard the parties. (Council of the European Union, 2019, C 384 I/86-87)

There are then other provisions that seem to confirm the persistent relevance of the CJEU's case law. Even at national level Art. 26 of the EU (WA) Act 2020 about "retained EU law and relevant separation agreement law" confirms the significance of the case law of the CJEU (UK Parliament, 2020). If, on the one hand, it is clear that judges are no longer bound by the case law of the CJEU on the interpretation of retained EU law, on the other hand, this does not exclude that they may take it into account. This was also explicitly suggested by Art. 6 of the EU Withdrawal Act of 2018, which reads that "a court or tribunal may have regard to anything done on or after exit day by the European Court, another EU entity or the EU so far as it is relevant to any matter before the court or tribunal" (UK Parliament, 2018).

This is understandable after all, since retained EU law has been shaped by the interpretation of the Luxembourg Court over the years. Moreover, one should not forget that the UK is a common law system based on the stare decisis principle, which inevitably tend to be conservative. This could represent another reason why the activity of the CJEU could be relevant even in the future, within the British borders.

\section{Final Remarks}

Brexit was a landmark event in the characterisation of the relationship between the EU and its Member States.
The "incoming tide" described by Lord Denning (1974) showed all its force in the moment of maximum friction; that is, the withdrawal of EU membership. However, even after Brexit, the inextricable knot that the membership created will not vanish magically in one blow. As this article demonstrated, Brexit set a milestone for EU law and the CJEU has been one of its main interpreters. In a nutshell, the CJEU has shed some light on the structure of the $\mathrm{EU}$ and the relationship between the EU and its Member States, confirming its key role in the interpretation of the Treaties and in the preservation of the smooth functioning of the EU legal order. From this standpoint, the legacy of Brexit is destined to last beyond the individual case of the UK and to affect the future of the EU legal order.

The main legacy is the Wightman case, where the Grand Chamber of the CJEU interpreted Art. 50 TEU. This was the first time that the CJEU engaged with the interpretation of this provision and aimed to clarify the functioning of the withdrawal process. Wightman disclosed the tensions between national sovereignty and EU membership and opened some potential issues in the exercise of national right to revocation of the withdrawal decision. As this article pointed out, the CJEU affirmed the existence of an unconditional right to repent and reverse the withdrawal process, which might bring about some systemic issues in the functioning of the negotiations for the withdrawal. Even though this was not the case for Brexit, the absence of any guarantees for the remaining Member States in the unilateral revocation of the withdrawal decision creates a precarious equilibrium in the application of Art. 50 TEU.

In addition, Brexit re-shaped to some extent the independence and the jurisdiction of the CJEU. As analysed, the tensions between the national composition of EU institutions and their supranational character reflected upon the composition of the EU judiciary and, controversially, upon the mandate of its Advocates General before the CJEU. The pending actions brought by British AG Sharpston are going to clarify how independent the EU judiciary is. The settlement of this case will provide further insights that will impact on general understanding of the role of the judiciary. As a second legacy, Brexit has thus forced the EU and the CJEU to reflect on the independence of its supranational institutions and the prevalence of the rule of law over political agreements.

The UK accession to the European Communities in 1972 had an impact over the style of the CJEU's decisions and on its legal reasoning (Pierdominici, 2020, p. 317) and on this basis more recently it has been argued that changes in the composition of the CJEU shall impact on the use of precedents in the case law of the CJEU (Fjelstul, 2018). Although possible, it is also true that the CJEU does not consider itself as bound to the stare decisis principle (Jacob, 2014). It is also likely that Brexit might produce some changes in the legal reasoning and style of decisions of the CJEU as had happened after the UK accession (Nicola, 2017), but this can only be tested in the long run. 
The third legacy of Brexit concerns the jurisdiction of the CJEU. As seen, if Brexit was supposed to cut the UK's relationship with the CJEU, the WA maintained its jurisdiction, which in practice extended beyond the transition period. The CJEU will maintain a crucial role and even at national level judges could take its case law into account as provided by the EU (Withdrawal) Act 2018. All this means that the legal knot cannot be definitely cut. It needs to be reassembled in the post-Brexit scenario, so that existing legal ties can be framed in the changed UK-EU relationships.

\section{Acknowledgments}

The article elaborates on a common reflection of the authors. However, Marta Simoncini authored sections 2, 4 and 6; while Giuseppe Martinico authored sections 1, 3 and 5 . We would like to thank the anonymous reviewers and the editors of the Special Issue for their comments and remarks. The usual disclaimers apply.

\section{Conflict of Interests}

The authors declare no conflict of interests.

\section{References}

Andy Wightman and Others v. Secretary of State for Exiting the European Union, C-621/18, ECLI:EU:C:2018: 999 (2018).

Avbelj, M., Fontanelli, F., \& Martinico, G. (Eds.). (2014). Kadi on trial: A multifaceted analysis of the Kadi judgment. London: Routledge.

Bogdanor, V. (2019). Beyond Brexit: Towards a British constitution. London: I.B. Tauris.

Bogdanor, V., Khaitan, T., \& Vogenauer, S. (2010). Should Britain have a written constitution? The Political Quarterly, 78(4), 499-517.

Bulmer (HP) Ltd v. J Bollinger SA, EWCA Civ 14, (1974).

Campos Sánchez-Bordona, M. (2018). Opinion of Advocate General Campos Sánchez-Bordona (Case C-621/18, ECLI:EU:C:2018:978). Luxembourg: Court of Justice of the European Union.

Canor, I. (2013). My brother's keeper? Horizontal solange: An ever closer distrust among the peoples of Europe. Common Market Law Review, 50(2), 383-421.

Conference of the Representatives of the Governments of the Member States. (2020, 29 January). Declaration by the conference of the representatives of the Governments of the Member States on the consequences of the withdrawal of the United Kingdom from the European Union for the Advocates-General of the Court of Justice of the European Union. Brussels: Council of the European Union. Retrieved from https://data.consilium.europa.eu/doc/document/ XT-21018-2020-INIT/en/pdf

Council of the European Union v. Eleanor Sharpston, C-423/20 P(R) and C-424/20 P(R), ECLI:EU:C:2020:
700 (2020).

Council of the European Union. (2019). Agreement on the withdrawal of the United Kingdom of Great Britain and Northern Ireland from the European Union and the European Atomic Energy Community. Official Journal of the European Union, 62(C384I). Retrieved from https://eur-lex.europa.eu/legalcontent/EN/TXT/PDF/?uri=CELEX:12019W/TXT(02) \&from $=E N$

Council of the European Union. (2020). Council Decision (EU) $2020 / 135$ of 30 January 2020 on the conclusion of the Agreement on the withdrawal of the United Kingdom of Great Britain and Northern Ireland from the European Union and the European Atomic Energy Community. Official Journal of the European Union, 63(L29). Retrieved from https://eur-lex. europa.eu/legal-content/EN/TXT/PDF/?uri=CELEX: 32020D0135\&from=EN

Court of Justice of the European Union. (2014). Opinion 2/13 pursuant to Article 218(11) TFEU on the draft agreement providing for the accession of the European Union to the Convention for the Protection of Human Rights and Fundamental Freedoms (ECLI:EU:C:2014:2454). Luxembourg: Court of Justice of the European Union.

Dicey, A. V. (1885). Introduction to the study of the law of the constitution. Oxford: Oxford All Souls College.

Eeckhout, P. (2015). Opinion 2/13 on EU accession to the ECHR and judicial dialogue: Autonomy or autarky. Fordham International Law Journal, 38(4), 955-992.

Eleanor Sharpston v. Council of the European Union and Representatives of the Governments of the Member States, T-550/20 R ECLI:EU:T:2020:416 (2020).

Elliott, M. (2020). The internal market bill: A perfect constitutional storm. Public Law for Everyone. Retrieved from https://publiclawforeveryone.com/ 2020/09/09/the-internal-market-bill-a-perfectconstitutional-storm

European Union. (2016a). Consolidated version of the Treaty on European Union. Official Journal of the European Union, 59(C202), 13-45. https://eurlex.europa.eu/resource.html?uri=cellar:2bf140bfa3f8-4ab2-b506-fd71826e6da6.0023.02/DOC_1 \&format=PDF

European Union. (2016b). Consolidated version of the Treaty on the Functioning of the European Union. Official Journal of the European Union, 59(C202), 47-199. Retrieved from https://eur-lex.europa.eu/ legal-content/EN/TXT/PDF/?uri=OJ:C:2016:202:FULL \&from $=\mathrm{EN}$

European Union. (2016c). 38. Declaration on Article 252 of the Treaty on the Functioning of the European Union regarding the number of AdvocatesGeneral in the Court of Justice. Official Journal of the European Union, 59(C202), 350. Retrieved from https://eur-lex.europa.eu/legal-content/EN/ TXT/PDF/?uri=OJ:C:2016:202:FULL\&from=EN

European Union. (2016d). Protocol (No 3) on the statute 
of the Court of Justice of the European Union. Official Journal of the European Union, 59(C202), 210229. Retrieved from https://eur-lex.europa.eu/legalcontent/EN/TXT/PDF/?uri=OJ:C:2016:202:FULL \&from $=\mathrm{EN}$

Fjelstul, J. C. (2018). Life after Brexit: The impact of common law judges at the court of justice of the European Union. Retrieved from https://static1.squarespace. com/static/56788b207086d7cddecdff48/t/ 5cbfae60eb3931525b1ac3f2/1556065889627/ Fjelstul_common_law.pdf

Frantziou, E., \& Eeckhout, P. (2017). Brexit and Article 50 TEU: A constitutionalist reading. Common Market Law Review, 54(3), 695-734.

Garner, O. (2020). True (bad) faith 2020? Part one: The commission infringement action against the United Kingdom for breach of the Withdrawal Agreement. European Law Blog. Retrieved from https://europeanlawblog.eu/2020/10/08/true-badfaith-2020-part-one-the-commission-infringementaction-against-the-united-kingdom-for-breach-ofthe-withdrawal-agreement

George, S. (1990). An awkward partner: Britain in the European community. Oxford: Oxford University Press.

Halberstam, D. (2020). Could there be a Rule of Law problem at the EU Court of Justice? The puzzling plan to let U.K. Advocate General Sharpston go after Brexit. Verfassungsblog. Retrieved from https:// verfassungsblog.de/could-there-be-a-rule-of-lawproblem-at-the-eu-court-of-justice

HM Government. (2020). United Kingdom internal market bill (HL Bill 135). London: HM Government. Retrieved from https://publications.parliament.uk/ pa/bills/lbill/58-01/135/5801135.pdf

Jacob, M. (2014). Precedents and case-based reasoning in the European Court of Justice. Cambridge: Cambridge University Press.

$\mathrm{JU}$ and Others v. Council, T-252/20, (pending). Retrieved from https://eur-lex.europa.eu/legal-content/EN/ TXT/?uri=CELEX\%3A62020TN0252

Kochenov, D. (2020). Humiliating the court? Irremovability and judicial self-governance at the ECJ today. Verfassungsblog. Retrieved from https:// verfassungsblog.de/humiliating-the-court

Kochenov, D., \& Butler, G. (2020a). It's urgent: The illegal appointment of a new Advocate General and what can be done to uphold the Rule of Law in the EU. Verfassungsblog. Retrieved from https:// verfassungsblog.de/its-urgent

Kochenov, D., \& Butler, G. (2020b). It's urgent II: The EU General Court temporarily suspends the attempted appointment of a new Advocate General. Verfassungsblog. Retrieved from https://verfassungsblog. de/its-urgent-ii

Kochenov, D., \& Butler, G. (2020c). It's urgent III: AG Sharpston dismissed in a radical move-The
Court of Justice proclaims its own lack of independence. Verfassungsblog. Retrieved from https:// verfassungsblog.de/its-urgent-iii

Martinico, G., \& Simoncini, M. (2020). Wightman and the perils of Britain's withdrawal. German Law Journal, 21(5), 799-814.

Nicola, F. (2017). Luxembourg judicial style with or without the UK. Fordham International Law Journal, 40(5), 1505-1534.

NV Algemene Transport- en Expeditie Onderneming van Gend \& Loos v. Netherlands Inland Revenue Administration, 26-62, ECLI:EU:C:1963:1 (1963).

Pech, L. (2020). The Schrödinger's Advocate General. Verfassungsblog. Retrieved from https:// verfassungsblog.de/the-schroedingers-advocategeneral

Pierdominici, L. (2020). The mimetic evolution of the Court of Justice of the EU: A comparative law perspective. London: Palgrave Macmillan.

Price v. Council, T-231/20 (pending).

$\mathrm{R}$ (Miller) v. Secretary of State for Exiting the European Union, EWHC 2768 (2016).

R (Miller) v. Secretary of State for Exiting the European Union, UKSC 5 (2017).

Representatives of the Governments of the Member States. (2020). Decision (EU) 2020/1251 of the Representatives of the Governments of the Member States of 2 September 2020 appointing three Judges and an Advocate-General to the Court of Justice. Official Journal of the European Union, 63(L292), 1-2. Retrieved from https://eur-lex.europa. eu/legal-content/EN/TXT/PDF/?uri=OJ:L:2020:292: FULL\&from $=E N$

Sarmiento, D. (2018). Brexit and EU citizenship after Wightman. Despite our Differences. Retrieved from https://despiteourdifferencesblog.wordpress.com/ 2018/12/12/brexit-and-eu-citizenship-afterwightman

Schütze, R. (2015). European Union Law. Cambridge: Cambridge University Press.

Shindler and Others v. Council, T-198/20 (pending).

Simoncini, M. (2009). Risk regulation approach to EU policy against terrorism in the light of the ECJ/CFI jurisprudence. German Law Journal, 10(11), 1526-1549.

UK Parliament. (2018). European Union (Withdrawal) Act 2018. London: UK Parliament. Retrieved from https://www.legislation.gov.uk/ukpga/2018/16/ contents/enacted

UK Parliament. (2020). European Union (Withdrawal Agreement) Act 2020. London: UK Parliament. Retrieved from https://www.legislation.gov.uk/ ukpga/2020/1/contents/enacted

Yassin Abdullah Kadi and Al Barakaat International Foundation v. Council of the European Union and Commission of the European Communities, C-402/05 P and C-415/05 P ECLI:EU:C:2008:461 (2008). 


\section{About the Authors}

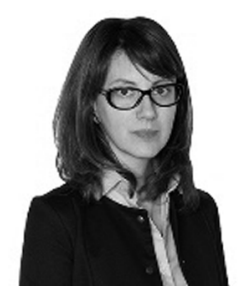

Marta Simoncini (PhD) is an Assistant Professor in administrative law at Luiss University, Rome. She has been an FWO Fellow at the University of Antwerp and King's College London, a Max Weber Fellow at the EUI and a Fellow at UCL. Her research interests cover European law and governance with a strong focus on discretionary powers and risk regulation. She published in peer-reviewed journals such as the Yearbook of European Law, Common Market Law Review, European Public Law and the European Journal of Risk Regulation. She also authored a monograph for Hart Publishing (2018).

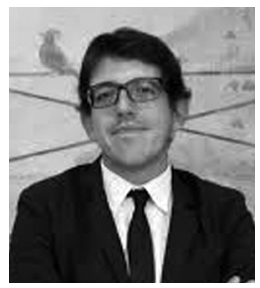

Giuseppe Martinico (PhD) is Full Professor of comparative public law at the Sant'Anna School of Advanced Studies, Pisa. Prior to joining the Sant'Anna School, he was García Pelayo Fellow at the Centro de Estudios Politicos y Constitucionales (CEPC), Madrid and Max Weber Fellow at the EUI. In Pisa he also serves as STALS Editor (www.stals.santanannapisa.it). He has published in peer-reviewed journals such as International Journal of Constitutional Law, European Journal of International Law, Yearbook of European Law, European Constitutional Law Review, European Public Law and European Law Journal. He is author of six monographs on European law and comparative federalism. 